\title{
Antimicrobial activity of caatinga biome ethanolic plant extracts against gram negative and positive bacteria
}

\section{Atividade antimicrobiana de extratos etanólicos do bioma Caatinga contra bactérias gram-negativas e positivas}

\author{
Maria da Conceição A. de Sá, ${ }^{*}$ Rodolfo de M. Peixoto, ${ }^{* *}$ Cristina da C. Krewer, ${ }^{* * *}$ Jackson Roberto G. da Silva Almeida, ${ }^{* * * *}$ \\ Agueda C. de Vargas, ${ }^{* * * *}$ Mateus M. da Costa*
}

\begin{abstract}
Resumo
A busca por tratamentos fitoterápicos intensificou-se nas últimas décadas. O uso abusivo das drogas antimicrobianas, a seleção de bactérias resistentes e as condições de manejo inadequadas são temas de impacto na medicina veterinária. Tendo em vista o acima descrito, objetivou-se avaliar a atividade antibacteriana de extratos etanólicos de plantas do bioma caatinga, contra patógenos de interesse veterinário. Foram utilizados seis extratos etanólicos de Amburana cearensis A.C.Smith, a Selaginella convoluta Arn.(Spring), a Hymenaea courbaril L., a Neoglaziovia variegata (Arruda) Mez., Bromelia laciniosa Mart. e Encholirium spectabile Mart. A atividade antibacteriana destes extratos foi testada contra bactérias gramnegativas e positivas. Determinou-se a concentração bactericida mínima (CBM) para cada extrato. Os ensaios foram realizados em triplicata. Para os extratos avaliados foram encontradas atividades antibacterianas nos gêneros estudados com exceção de Proteus spp., Nocardia spp., Staphylococcus caprae e Streptococcus agalactiae. A umburana (A. cearensis) e o caroá (Neoglaziovia variegata) mostraram os menores valores de CBM. Considerando o baixo custo da fitoterapia e a atividade das plantas do bioma caatinga, outros estudos acerca da atividade in vivo e da caracterização fitoquímica tornam-se necessários.
\end{abstract}

Palavras-chave: extratos etanólicos, testes de sensibilidade, patógenos, veterinária.

\begin{abstract}
The search for phytotherapeutic (medicinal plant) treatments has been intensified in recent decades. The abusive use of antimicrobial drugs, selection of resistant bacteria and inadequate handling conditions are issues that have an impact on veterinary medicine. With this in mind, the objective of this study was to evaluate the antibacterial activity of ethanolic extracts of caatinga biome plants against pathogens of veterinary interest. Six ethanolic extracts of plants existing in the Caatinga biome of the Pernambuco semi-arid region were used, namely: Amburana cearensis A.C.Smith, Selaginella convoluta Arn.(Spring), Hymenaea courbaril L., Neoglaziovia variegata (Arruda) Mez., Bromelia laciniosa Mart. and Encholirium spectabile Mart. The antibacterial activity of these extracts was tested against gram negative and positive bacteria. The minimum bactericidal concentration (MBC) for each extract was determined. Tests were carried out in triplicate. Antibacterial activities in the genuses studied were found for the extracts evaluated, with the exception of Proteus spp., Nocardia spp., Staphylococcus caprae and Streptococcus agalactiae. Amburana cearensis and Neoglaziovia variegata exhibited the lowest MBC values. Considering the low cost of phytotherapy and the activity of the caatinga biome plants, other studies related to the activity in vivo and the phytochemical characterization become necessary.
\end{abstract}

Keywords: ethanolic extracts, sensitivity tests, pathogens, veterinary medicine.

\section{Introduction}

Resistance to antimicrobial agents in human and animal health is a serious problem which requires not only the study of new approaches for the treatment of bacterial infections but also research for the development of new pharmaceuticals (Lathers, 2002). Therefore, the search for antibacterial properties of plant extracts has been stimulated and intensified (Miguel \& Miguel, 1999, Stein et al., 2005).

\footnotetext{
* Laboratório de Microbiologia e Imunologia Animal da Universidade Federal do Vale do São Francisco, 56300-990, Petrolina,PE, Brasil

** Instituto Federal de Educação, Ciência e Tecnologia do Sertão Pernambucano, Campus Floresta, 56400-000, Floresta, PE, Brasil

*** Departamento de Morfologia da Universidade Federal de Santa Maria, 97119-900, Santa Maria, RS, Brasil

**** Núcleo de Estudos e Pesquisas de Plantas Medicinais da Universidade Federal do Vale do São Francisco, 56304-205, Petrolina, PE, Brasil

**** Departamento de medicina veterinária preventiva da Universidade Federal de Santa Maria, 97119-900, Santa Maria, RS, Brasil Autor para correspondência: Mateus M. da Costa. E-mail: mateus.costa@univasf.edu.br; Tel. +55813986 3800 Fax: +55813986 3801.
} 
Phytotherapy (medicinal plant therapy) is a method empirically used by humanity from ancient times until now (Weckesser et al., 2007). It is estimated that substances derived from plants constitute approximately $25 \%$ of medically prescribed agents in industrialized countries (Rates, 2001). In recent years, the prescription of phytotherapeutic products has grown in medical and veterinary clinical practice (Ryan et al., 2001).

Within this perspective, it is expected Brazil to be in a privileged position considering its extensive and diversified flora, holding approximately one third of the world's plants (Yunes, 2001). The Caatinga biome is the main ecosystem in the Brazilian Northeast Region, extending over the domain of semi-arid climates in an area of $73,683,649$ ha, $6.83 \%$ of national territory, occupying the states of Bahia, Ceará, Piauí, Pernambuco, Rio Grande do Norte, Paraíba, Sergipe, Alagoas, Maranhão and Minas Gerais (Brasil, 2008). It contains various plants species of phytotherapeutic interest. In this diversity of plants we find Amburana cearensis A.C.Smith, Selaginella convoluta Arn.(Spring), Hymenaea courbaril L., Neoglaziovia variegata (Arruda) Mez., Bromélia laciniosa Mart., and Encholirium spectabile Mart, plants with a history of use for diverse types of illnesses, with some being sold in public markets (Agra, et al., 2005). Hymenaea courbaril L., belongs to the Fabaceae family and phytochemical studies have detected the presence of diterpenes in the resin exuded through the trunk and in bark extracts of this plant (Nogueira et al., 2001). Terpenes have various biological activities, such as protection against infections and insect attacks (Robberts et al., 1997). A study developed by Vera et al. (2006) showed the activity of plants from the Brazilian Northeast against isolated aerobic bacteria of patients with leishmaniasis. The objective of this study was to evaluate the antibacterial activity of ethanolic extracts of plants from the caatinga biome against pathogens of veterinary interest.

\section{Material and methods}

\section{Location of the experiment}

This study was developed from February 2007 to May 2008 in the Animal Microbiology and Immunology Laboratory of Universidade Federal do Vale do São Francisco.

Isolates used

The antibacterial activity of these extracts was tested against the following pathogens of veterinary interest: Escherichia coli, Enterococcus faecalis, Klebsiella spp. , Salmonella spp., Staphylococcus aureus, Pseudomonas aeruginosa, Rhodococcus equi, Listeria spp., Corynebacterium spp., Aeromonas spp., Proteus spp., Yersinia enterocolitica, Staphylococcus epidermidis, Staphylococcus intermedius, Streptococcus agalactiae, Streptococcus suis, Nocardia spp., Vibrio spp., Micrococcus spp, Staphylococcus caprae and Edwardsiella tarda.

\section{Collection of plant material}

The plant material of Amburana cearensis (umburana de cheiro or cumaru), Encholirium spectabile (macambira de fleche), Hymenaea courbaril (Jatobá), Neoglaziovia variegata ( caroá), Bromelia laciniosa (macambira de porco) and
Selaginella convoluta, whose common name is jericó collected in the municipality of Lagoa Grande, PE. The plant material was collected and identified by a specialist in the area. Herbarium specimens of the species were codified and placed in the Herbarium at the Universidade Federal do Vale do São Francisco (HVASF). Collection was made of the whole plant of Selaginella convoluta, Encholirium spectabile, Bromélia laciniosa and Neoglaziovia variegata, and the bark of the trunk of Hymenaea courbaril and Amburana cearensis.

\section{Preparation of the crude}

All material was processed at the laboratory of the Medicinal Plant Studies and Research Center .... It was then submitted to drying in a forced air circulation laboratory oven at a temperature of $40^{\circ} \mathrm{C}$ for 72 hours and protected from light and moisture. After this period, the material was ground to powder and macerated for three days in a percolator with ethanol at $95 \%$. The material underwent filtration under a vacuum system, the extract was then concentrated in a rotary evaporator under reduced pressure $\left(60^{\circ} \mathrm{C}\right)$ to approximately $1 / 5$ of the original volume. The extract was then clarified through alcohol extractions for three days, with the final extract being conserved in an amber glass container under refrigeration.

\section{In vitro sensitivity test}

For determination of antibacterial activity, a microdilution protocol was used following descriptions of the M7-A4 document of the NCCLS (NCCLS, 1997). For this purpose, $0.01 \mathrm{~g}$ of extract was diluted in $10 \mathrm{~mL}$ of ethanol. The stock solution was diluted in a serial to obtain the concentrations of $500,250,125,62.5,31.25,15.62,7.81$ and $3.90 \mu \mathrm{g} / \mathrm{mL}$. In inoculum preparation, colonies maintained in Muller-Hinton Agar were used to obtain a bacterial suspension with turbidity equivalent to 0.5 turbidity on the MacFarland scale. From this suspension, $10 \mu \mathrm{L}\left(1 \times 10^{4}\right.$ UFC) was inoculated in each well containing a dilution of the ethanolic extract. From the dilution where visible bacterial growth was not observed, an aliquot of $10 \mu \mathrm{l}$ was removed, seeding it on the $\mathrm{MH}$ Agar surface and incubating it for $24 \mathrm{~h}$ at $37^{\circ} \mathrm{C}$. Afterwards, the minimum bactericidal concentration (MBC) was determined as the smallest concentration of the ethanolic extract under study capable of causing the death of the inocula. Tests were performed in triplicate.

\section{Results and discussion}

The caatinga is the only exclusively Brazilian biome, but is often forgotten from the scientific point of view. Even under the supposition of little biodiversity, this is not justified in virtue of its broad flora and fauna composition (Leal et al., 2003). This diversity supports an as yet unexplored great biotechnological potential.

Members of the Enterobactericeae family are considered as important pathogens for animals, as well as a large public health problem. The resistance of these groups of microorganisms is very well known and is associated with the horizontal exchange of resistance plasmids (Sherley et al., 2004). In this study, the antibacterial activity of the extracts against E. coli, Klebsiella spp., Salmonella spp., Y. 
enterecolitica and Edwardsiella spp. (Table 1) was observed. In relation to the bacterial groups Proteus spp., Nocardia spp., $S$. caprae and $S$. agalactiae, the activity of the extracts was the same as observed in the alcohol control, proving the absence of activity. For E. coli, it was observed that Neoglaziovia variegata and Encholirium spectabile presented good antimicrobial activity, with an average MBC of $83.33 \mu \mathrm{L}$ and $125 \mu \mathrm{L}$ respectively, with the latter also showing activity against Corynebacterium spp. (41.67 $\mu \mathrm{L})$. Bravo et al. (1999) reported activity of Amburana cearensis against E.coli and Shigella flexneri. In our study, this activity was observed for all the enteric pathogens, although for Edwardsiella these values were the lowest $(62.5 \mathrm{~mL})$. In relation to Salmonella spp. lower activity was observed (104.2) for the Selaginella convoluta extract. For $Y$. enterocolitica, in addition to Hymenaea courbaril $(62.50 \mu \mathrm{L})$, Neoglaziovia variegata and Selaginella convoluta also presented good antibacterial activity at $83.33 \mu \mathrm{L}$ and $93.75 \mu \mathrm{L}$, respectively.

Among the main pathogens found in water are Aeromonas spp. Vibrio spp. and Pseudomonas spp. When the sensitivity of Aeromonas spp. and Vibrio spp. was analyzed, it was observed that, with the exception of Neoglaziovia variegata (62.5 $\mu \mathrm{L}$ and $31.25 \mu \mathrm{L}$, respectively) and Amburana cearensis (62.5 $\mu \mathrm{L}$ and $31.25 \mu \mathrm{L}$, respectively), the other extracts presented low activity (Table 1). Oliveira et al. (2007), upon analyzing phases of different plant extracts of the Southeast region of Brazil, showed the absence of activity for $P$ seudomonas aeruginosa. The resistance of $P$. aeruginosa to various antimicrobial compounds is widely recognized (Figueiredo et al., 2007).

In relation to the low percentage of sensitivity of the extracts against the isolates, in the Gram negative bacteria (Figure 1), the cell wall is internally and externally constituted by membranes separated by glycopeptide (Hirsh \& Zee, 2003); this double protection cellular composition reduces the action of the antibacterial compounds. In addition, it may be observed that the origin of collection of these pathogens is the southern region of Brazil, where the bacteria have a high rate of resistance associated with excessive use of the antimicrobial agents (Costa et al., 2006).

Gram positive cocci are related to diverse infectious conditions in veterinary medicine, especially mastitis and pyodermititis, often having public health implications, especially
Staphylococcus aureus (Fagundes \& Oliveira, 2004). Considering the species Staphylococcus spp., the extract of Hymenaea courbaril showed the lowest MBC. The antibacterial activity of the plant extracts of the caatinga biome against Streptococcus suis, showed the lowest MBC for Amburana cearensis, Bromélia laciniosa and Selaginella convoluta $(83.33 \mu \mathrm{L})$. In relation to Micrococcus spp. greatest sensitivity was observed to the ethanolic extract Neoglaziovia variegata $(52.08 \mu \mathrm{L})$.

The Gram positive bacilli, especially those of the soil, are associated with the origin of resistance of diverse antimicrobial compounds. These are also important veterinary pathogens, principally in immunosuppressed hosts, where the treatment with antimicrobial drugs might not be successful and might cause its death. Therefore, the search for alternatives must be considered (D'Costa et al, 2006). For Rhodococcus equi, the extract with greatest antibacterial activity was Neoglaziovia variegata $(93.75 \mu \mathrm{L})$. For Listeria spp., for its part, the greatest inhibition occurred for the extract of Amburana cearensis $(125 \mu \mathrm{L})$. In contrast, for Corynebacterium spp., the greatest activity was observed for Amburana cearensis (41.67 $\mu \mathrm{L}$ ) and Encholirium spectabile (41.67 $\mu \mathrm{L})$.

The abusive use of antimicrobial drugs, the selection of resistant bacteria and inadequate management conditions are themes that have an impact on veterinary medicine (Mathew et al., 2007). There are diverse studies with plant extracts for determination of antihelmintic activity; nevertheless, there is a lack of studies for determination of antibacterial activity (Rochfort et al., 2008). In addition, when they are undertaken, there is no connection among the plants and object of study, as well as the methodologies evaluated. In our study, antibacterial activity was found in most of the extracts evaluated; nevertheless, in general, Amburana cearensis and Neoglaziovia variegata showed the lowest values of MBC. The extracts evaluated were not active for Proteus spp., Nocardia spp., S. caprae and S. agalactiae.

\section{Conclusion}

Considering the low cost of phytotherapy and the activity of the caatinga biome plants, other studies related to the activity in vivo and the phytochemical characterization become necessary.

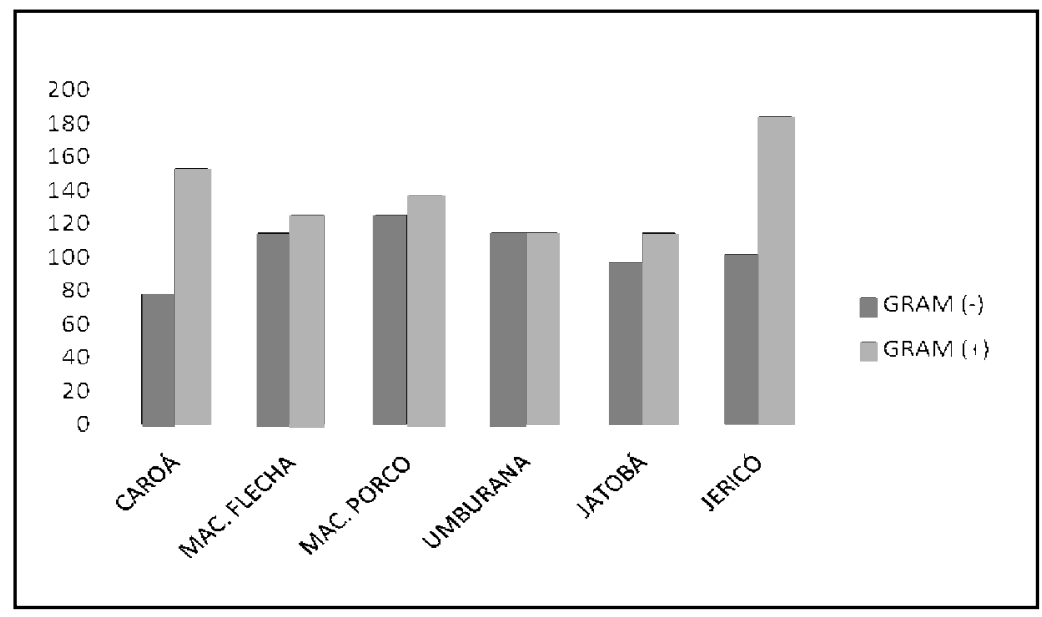

Figura 1: Means $(\mu \mathrm{L})$ of inhibition of the ethanolic extracts of plants existing in the Caatinga biome of the Pernambuco semi-arid region against Gram (-) and Gram (+) bacteria. 
Table 1: Susceptibility of the main pathogens of importance to Veterinary medicine in the face of plant extracts from the Caatinga Biome

\begin{tabular}{|c|c|c|c|c|c|c|c|c|c|c|c|c|c|c|c|c|c|c|}
\hline \multirow[b]{3}{*}{ MICROORGANISM } & \multicolumn{3}{|c|}{ CAROÁ } & \multicolumn{3}{|c|}{ MAC. DE FLECHA } & \multicolumn{3}{|c|}{ MAC. PORCO } & \multicolumn{3}{|c|}{ UMBURANA } & \multicolumn{3}{|c|}{ JАTOBÁ } & \multicolumn{3}{|c|}{ JERICÓ } \\
\hline & \multicolumn{2}{|c|}{$\mathrm{Mbc}$} & \multirow{2}{*}{$\begin{array}{r}\text { Alcohol } \\
\text { Mean } \\
\end{array}$} & \multicolumn{2}{|l|}{$\mathrm{Mbc}$} & \multirow{2}{*}{\begin{tabular}{r|} 
Alcohol \\
Mean
\end{tabular}} & \multicolumn{2}{|l|}{$\mathrm{Mbc}$} & \multirow{2}{*}{$\begin{array}{r}\text { Alcohol } \\
\text { Mean }\end{array}$} & \multicolumn{2}{|c|}{ Mbc } & \multirow{2}{*}{$\begin{array}{r}\text { Alcohol } \\
\text { Mean }\end{array}$} & \multicolumn{2}{|c|}{ Mbc } & \multirow{2}{*}{$\begin{array}{r}\text { Alcohol } \\
\text { Mean }\end{array}$} & \multicolumn{2}{|c|}{$\mathrm{Mbc}$} & \multirow{2}{*}{$\begin{array}{r}\text { Alcohol } \\
\text { Mean }\end{array}$} \\
\hline & Range & Mean & & Range & Mean & & Range & Mean & & Range & Mean & & Range & Mean & & Range & Mean & \\
\hline Escherichia coli & $62.5-125$ & 83.33 & 354.17 & $0-125$ & 125 & 354.17 & $0-125$ & 125 & 354.17 & $125-250$ & 166.7 & 354.17 & $62.5-125$ & 104.2 & 354.17 & $62.5-250$ & 145.8 & 354.17 \\
\hline Enterococcus faecalis & $0-125$ & 125 & 291.67 & $0-500$ & 375 & 291.67 & $0-250$ & 187.5 & 291.67 & $0-250$ & 187.5 & 291.67 & $62.50-250$ & 187.5 & 291.67 & $0-500$ & 375 & 291.67 \\
\hline Klebsiella spp. & $62.5-250$ & 145.8 & 114.58 & $62.50-250$ & 156.3 & 114.58 & $0-250$ & 187.5 & 114.58 & $62.5-125$ & 83.33 & 114.58 & $31.5-250$ & 135.5 & 114.58 & $250-250$ & 250 & 114.58 \\
\hline Salmonella spp. & $62.5-250$ & 145.8 & 250 & $125-250$ & 166.7 & 250 & $125-500$ & 250 & 250 & $62.5-250$ & 145.8 & 250 & $62.5-250$ & 145.8 & 250 & $62.5-125$ & 104.2 & 250 \\
\hline Staphylococcus aureus & $62.5-250$ & 145.8 & 416.7 & $62.50-250$ & 145.8 & 416.7 & $62.50-250$ & 145.8 & 416.7 & $125-250$ & 145.8 & 416.7 & $62.5-125$ & 104.2 & 416.7 & $62.5-500$ & 270.8 & 416.7 \\
\hline Pseudomonas aeruginosa & $125-250$ & 166.7 & 166.67 & $0-250$ & 250 & 166.7 & $0-250$ & 187.5 & 166.7 & $125-250$ & 166.7 & 166.67 & 125-125 & 125 & 166.7 & $0-125$ & 125 & 166.7 \\
\hline Rhodococcus equi & $0-125$ & 93.75 & 333.33 & $0-250$ & 187.5 & 333.33 & $0-250$ & 187.5 & 333.33 & $0-250$ & 187.5 & 333.33 & $0-250$ & 156.3 & 333.33 & $0-125$ & 125 & 333.33 \\
\hline Listeria spp. & $125-250$ & 166.7 & 208.33 & $125-250$ & 208.33 & 208.33 & $125-250$ & 166.7 & 208.33 & $125-125$ & 125 & 208.33 & 125.5 & 291.7 & 208.33 & $125-250$ & 166.7 & 208.33 \\
\hline Corynebacterium spp. & $250-500$ & 333.33 & 437.5 & $31.25-62.50$ & 41.67 & 437.5 & $31.25-62.50$ & 52.08 & 437.5 & $31.25-62.50$ & 41.67 & 437.5 & $62.5-62.5$ & 62.5 & 437.5 & $31.25-62.50$ & 41.67 & 437.5 \\
\hline Aeromonas spp. & $0-62.50$ & 62.5 & 125 & $0-125$ & 125 & 125 & $0-500$ & 500 & 125 & $0-62.50$ & 62.5 & 125 & $0-62.50$ & 62.5 & 125 & $0-250$ & 250 & 125 \\
\hline Proteus spp. & $0-250$ & 250 & 250 & 0 & 0 & 250 & 0 & 0 & 250 & $0-500$ & 281.3 & 250 & $0-500$ & 281.3 & 250 & $62.5-500$ & 270.8 & 250 \\
\hline Yersinia enterocolitica & $62.5-125$ & 83.33 & 104.2 & $62.5-125$ & 104.2 & 104.2 & $62.5-250$ & 145.8 & 104.2 & $62.5-125$ & 104.2 & 104.2 & $62.5-62.50$ & 62.5 & 104.2 & $31.25-125$ & 93.75 & 104.2 \\
\hline Staphylococcus epidermidis & $62.50-125$ & 104.2 & 83.33 & $62.5-250$ & 145.8 & 83.33 & $62.5-125$ & 104.2 & 83.33 & $125-125$ & 125 & 83.33 & $0-62.50$ & 62.5 & 83.33 & $250-500$ & 416.7 & 83.33 \\
\hline Staphylococcus intermedius & $31.25-62.50$ & 41.67 & 41.67 & $31.25-125$ & 72.92 & 41.67 & $62.50-62.50$ & 62.5 & 41.67 & $31.25-31.25$ & 31.25 & 41.67 & $62.50-62.50$ & 62.5 & 41.67 & $62.5-62.50$ & 62.5 & 41.67 \\
\hline Streptococcus agalactiae & $0-500$ & 375 & 104.17 & $0-500$ & 500 & 104.17 & $250-250$ & 250 & 104.17 & $250-250$ & 250 & 104.17 & $125-500$ & 291.7 & 104.17 & $250-250$ & 250 & 104.17 \\
\hline Streptococcus suis & $125-250$ & 166.7 & 104.17 & $125-125$ & 125 & 104.17 & $62.50-125$ & 83.33 & 104.17 & $62.5-125$ & 83.33 & 104.17 & $125-125$ & 125 & 104.17 & $62.50-125$ & 83.33 & 104.17 \\
\hline Nocardia spp. & $125-125$ & 125 & 41.67 & $125-250$ & 166.7 & 41.67 & $125-500$ & 291.7 & 41.67 & $125-125$ & 125 & 41.67 & $62.50-125$ & 104.2 & 41.67 & $125-250$ & 166.7 & 41.67 \\
\hline Vibrio spp. & $31.25-31.25$ & 31.25 & 62.5 & $31.25-62.50$ & 52.08 & 62.5 & $31.25-125$ & 72.92 & 62.5 & $31.25-31.25$ & 31.25 & 62.5 & $15.62-125$ & 67.71 & 62.5 & $15.62-125$ & 57.29 & 62.5 \\
\hline Micrococcus spp. & $31.25-62.50$ & 52.08 & 83.33 & $62.5-125$ & 104.2 & 83.33 & $62.5-125$ & 104.2 & 83.33 & 125-125 & 125 & 83.33 & $62.50-125$ & 104.2 & 83.33 & $62.50-125$ & 83.33 & 83.33 \\
\hline Staphylococcus caprie & $125-250$ & 208.3 & 125 & $125-250$ & 208.33 & 125 & $125-250$ & 208.3 & 125 & $250-500$ & 333.33 & 125 & $125-250$ & 208.3 & 125 & $125-500$ & 291.7 & 125 \\
\hline Edwadisiella spp. & $62.50-62.50$ & 62.5 & 104.17 & $125-250$ & 166.7 & 104.17 & $62.5-125$ & 104.2 & 104.17 & $62.50-62.50$ & 62.5 & 104.17 & 62.50125 & 83.33 & 104.17 & $62.50-125$ & 83.33 & 104.17 \\
\hline
\end{tabular}




\section{References}

AGRA, M.F. Medicinais e produtoras de princípios ativos. In: SAMPAIO, E.V.S. P.; PAREYN, F.G.C.; FIGUEIRÔA, J.M.; SANTOS JUNIOR, A.G. (Org.) Espécies da flora nordestina de importância econômica potencial. Recife: Associação de Plantas do Nordeste. p. 135-198, 2005.

Brasil - Instituto Brasileiro do Meio Ambiente e dos Recursos Renováveis Ecossistemas Brasileiros - Caatinga, 2008. http:// www.ibama.gov.br/ecossistemas/caatinga.htm, accessed in May 2008.

BRAVO J.A.; SAUVAIN M.; GIMENEZ, T.A.; MUÑOZ, O.V.; CALLAPA, J.; MEN-OLIVIER, L.L.; MASSIOT, G.; LAVAUD, C. Bioactive phenolic glycosides from Amburana cearensis. Phytochemistry, v. 50, p. 7174, 1999.

COSTA, M.M.; SILVA, M.S.; SPRICIGO, D.A.; WITT, N.M.; MARCHJORO, S. B.; KOLLING, L.; VARGAS, A.P.C. Caracterização epidemiológica e perfil de resistência aos antimicrobianos de Escherichia coli isoladas de criatórios suínos do sul do Brasil. Pesquisa Veterinária Brasileira, v. 26, p. 5-8, 2006.

D“COSTA, V.M.; MCGRANN, K.M.; HUGHES, D.W.; WRIGHTI, G. D. Sampling the antibiotic resistome. Science, v. 311, p. 374-377, 2006.

FAGUNDES, H.; OLIVEIRA, C.A.F. Infecções intramamárias causadas por Staphylococcus aureus e suas implicações em saúde pública. Ciência Rural v. 34, n. 44, p. 1315-1320, 2004.

FIGUEIREDO, E.A.P.; RAMOS, H.; MACIEL, M.A.V.; VILAR, M.C.M.; LOUREIRO, N.G.; PEREIRA, R.G. Pseudomonas Aeruginosa: Frequência de Resistência a Múltiplos Fármacos e Resistência Cruzada entre Antimicrobianos no RecifelPE. Revista Brasileira de Terapia Intensiva v. 19, n. 4, p. 421-427, 2007.

LATHERS, C.M. Clinical Pharmacology of Antimicrobial Use in Humans and Animals. The Journal of Clinical Pharnacology, n. 42, p. 587600, 2002.

HIRSH, D.C.; ZEE, Y.C. Microbiologia veterinária. Rio de Janeiro: Guanabara Koogan, p. 59-61, 2003.

LEAL, I.R.; TABARELLI, M.; CARDOSO SILVA, J.M. Ecologia e Conservação da Caatinga. 2. ed. Recife: Editora Universitária, p. 804, 2003.

MATHEW, A. G.; CISSELL, R.; LIAMTHONG, S. Antibiotic Resistance in Bacteria Associated with Food Animals: A United States Perspective of Livestock Production. Foodborne pathogens and disease. v. 4, n. 2, p. 115-133, 2007.
MIGUEL, M.D.; MIGUEL, O.G. Desenvolvimento de fitoterápicos. São Paulo: Tecmedd, p.115, 2004.

NOGUEIRA, R.T.; SHEPHERD, G.J.; LAVERDE, J.A.; MARSAIOLI, A.J.; LAMAMURA, P.M. Clerodane-type diterpenes from the seed pods of Hymenaea courbarilvar. stilbocarpa. Phytochemistry. v. 58, p. 11531157, 2001.

OLIVEIRA, D.F.; PEREIRA, A.C.;FIGUEIREDO, H.C.P.; CARVALHO, D.A.; SILVA, G.; NUNES, A.S.; ALVES, D.S.; CARVALHO, H.W.P. Antibacterial activity of plant extracts from Brazilian southeast region. Fitoterapia. v. 78, p. 142-145, 2007.

RATES, S.M.K. Plants as source of drugs. Toxicon. v. 39, p. 603-613, 2001.

ROBBERS, J.E.; SPEEDIE, M.K.; TYLER, V.E. Terpenóides In: Farmacognosia e Farmacobiotecnologia. Williams \& Wilkins. Baltimore, MA - USA, 1997.

ROCHFORT, S.; PARKER, A.J.; DUNSHEA, F. R. Plant bioactives for ruminant health and productivity. Phytochemistry. v. 69, p. 299-322, 2008.

RYAN, T.; WILKINSON, J.M.; CAVANAGH, H.M.A. Antibacterial activity of raspberry cordial in vitro. Research in Veterinary Science. v. 7, p. 155-159, 2001.

SHERLEY, M.; GORDON, D.M.; COLLIGNON, P.J. Evolution of multiresistance plasmids in Australian clinical isolates of Escherichia coli. Microbiology. v.150, p.1539-1546, 2004.

STEIN, A.C.; SORTINO, M.; AVANCINI, C.;ZACCHINO, S.; POSER, G.V. Ethnovegeterinary medicine in the search for antimicrobial agents: Antifungal activity of some species of Pterocaulon (Asteraceae). Journal of Ethnopharnacology. v. 99, p. 211-214, 2005.

VERA, L.A.; MACEDO, J.L.S.; CIUFFO, I.A.; SANTOS, C.G.; SANTOS, J.B. Sensibilidade antimicrobiana de baterias aeróbicas isoladas de úlceras leishmanióticas, em Corte de pedra, BA. Revista da Sociedade Brasileira de Medicina Tropical. v. 39, p. 47-50, 2006.

YUNES, R.A.; PEDROSA, R.C.; CECHINEL, F.V. Fármacos e fitoterápicos: a necessidade do desenvolvimento da indústria de fitoterápicos e fitofármacos no Brasil. Quím Nova. v. 24, n. 1, p. 147152, 2001.

WECKESSER, S.; ENGEL, K.; SIMON-HAARHAUS, B.; WITTMER, A.; PELZ, K.; SCHEMPP, C.M. Screening of plant extracts for antimicrobial activity against bacteria and yeasts with dermatological relevance. Phytomedicin. v. 14, p. 508-516, 2007. 